\title{
Pathophysiologic Evidence of Gentamicin Nephrotoxicity in Neonatal Puppies
}

\author{
RICHARD H. COWAN, ALINA F. JUKKOLA, AND BILLY S. ARANT, JR. ${ }^{\text {Hit }}$ \\ The Pediatric Research Laboratory, Departments of Pediatrics and Pathologv, University of Tennessee Center for the \\ Health Sciences, Memphis, Tennessee, USA
}

\begin{abstract}
Summary
Newborn puppies were paired $(n=21$ pairs) at birth, given gentamicin $(5 \mathrm{mg} / \mathrm{kg} / \mathrm{day}$ for 7 days and then $7.5 \mathrm{mg} / \mathrm{kg} / \mathrm{day})$ or saline intramuscularly (IM) and studied at 10, 20, or 30 days of age. Peak gentamicin concentrations correlated neither with total body water nor extracellular fluid volume. The ratio of outer/inner cortical gentamicin concentrations increased with therapy $(n=$ $0.579 ; P<0.01)$. Pathologic changes in proximal tubular cells of superficial and juxtamedullary cortices corresponded to tissue accumulation of gentamicin. Inulin clearance was lower but not statistically different in gentamicin puppies at 20 and 30 days, but tubular reabsorption of phosphate was lower at 30 days $(P<0.02)$. Plasma creatinine decreased during the first month of life in both control and gentamicin puppies $(n=-0.370 ; P<0.02)$ and was not different between puppies even at 20 and 30 days when tubular damage was marked. No differences in urine sediment, osmolarity, glucose, and protein concentrations were noted between paired animals. Mean values of gentamicin half-life in gentamicin (control) puppies decreased from $80.3(84.0)$ min at 10 days to 45.3 (50.3) $\mathrm{min}$ at 20 days, but increased to $61.0(40.0 ; P<0.05) \mathrm{min}$ at 30 days. Similar studies in older puppies and adult animals given gentamicin resulted in an increase in plasma creatinine and gentamicin half-life within 10 days. Results of these studies confirmed that gentamicin nephrotoxicity occurred within 10 days in puppies treated from birth. The relative tolerance of the neonatal puppy to the toxic effects of gentamicin was attributed to the distribution of renal blood flow predominantly to juxtamedullar nephrons at birth which spared superficial nephrons from gentamicin accumulation and toxicity until renal blood flow was redistributed to the outer cortex and filtration in superficial nephrons began after the first wk of life.
\end{abstract}

\section{Speculation}

The relative tolerance of the neonate to the nephrotoxic effects of gentamicin and perhaps other aminoglycosides can be explained by the distribution of renal blood flow during development. Nephrons in the juxtamedullary cortex of the neonate receive a major fraction of renal blood flow initially and manifest gentamicin toxicity earlier than do nephrons in the outer cortex. Any impairment to nephron function in the inner cortex of the neonatal kidney during 7 to 10 days of gentamicin therapy would be offset by the successive contribution of more superficial nephrons to overall renal function. Once filtration has begun in all nephrons, gentamicin nephrotoxicity in the infant is comparable to the adult.

Gentamicin nephrotoxicity has been demonstrated to occur within 10 days of initiating therapy in human adults, and the first clinical evidence is usually an increase in plasma creatinine concentration $\left(P_{(r)}\right)(45)$. The severity of pathologic and functional changes in kidneys of adult animals has been related directly to gentamicin accumulation within the renal cortex $(16,17,27)$.
Gentamicin is filtered by the adult kidney and reabsorbed primarily across apical membranes of proximal tubular cells $(22,33$, 40) where it is either incorporated into lysosomes or excreted in the urine. Basolateral transport of gentamicin into tubular cells has been suggested by in vitro experiments (33). Neither tubular secretion of gentamicin nor reentry of the drug into the circulation has been reported, and gentamicin has been shown to persist in the renal cortex of humans and rats for wk or months after the last administered dose $(15,36)$.

Gentamicin is prescribed commonly for premature infants, but nephrotoxicity in neonates is rarely described. The assumption that the newborn infant is more tolerant of the nephrotoxic effects of gentamicin has been based mainly on the failure of $P_{C}$ to increase during 7 to 10 days of therapy (28).

The purpose of this study was to determine if gentamicin accumulates in the neonatal kidney as it does in that of the adult and, if so, to explain why the neonate fails to demonstrate clinical evidence of gentamicin nephrotoxicity. The newborn canine puppy was selected for study because evidence of nephrotoxicity $(1,45)$ and gentamicin accumulation in kidneys of canine and human adults is similar at comparable drug doses $(12,14,44)$ and because glomerular filtration rate (GFR) during development in the puppy (4) closely follows the developmental pattern reported for premature infants (3).

\section{MATERIALS AND METHODS}

\section{PAIRED STUDIES}

Healthy mongrel puppies were paired with littermates for birthweight. One puppy in each pair was given gentamicin $(5.0 \mathrm{mg} /$ $\mathrm{kg}$ /day for 7 days, then $7.5 \mathrm{mg} / \mathrm{kg} /$ day until the day of study), and the other puppy was given an equal volume of $0.9 \% \mathrm{NaCl}$ solution: both were given in divided doses as twice daily intramuscular (IM) injections. All puppies were handled similarly and remained with their mother whose milk provided the only source of nourishment. Daily morning body weights were recorded for each puppy. $P_{{ }^{\prime} r}(3)$ as well as peak and trough plasma gentamicin $\left(P_{{ }_{i}}\right)$ at $45 \mathrm{~min}$ and $14 \mathrm{hr}$ after gentamicin administration were obtained on the first day of life and on the day of study.

A total of 21 acute paired experiments were performed in puppies anesthetized with pentobarbital $(15$ to $30 \mathrm{mg} / \mathrm{kg})$ at 10 $(n=9), 20(n=6)$, or $30(n=6)$ days of age. Methods used in the preparation and monitoring of this animal model have been described previously (4). Urine was obtained by needle aspiration of the surgically exposed bladder at the outset of each experiment for osmolarity (model 63-31 osmometer; Advanced Instruments, Needham Heights, MA), for the concentration of protein (turbidometric method, 3\% sulfosalicylic acid) and glucose (glucose hexokinase method; Sigma Chemical Co., St. Louis, MO) and for microscopic examination of the centrifuged sediment; cells and casts were quantitated in a hemocytometer. Extracellular fluid volume (ECFV) was measured as radiosulfate ${ }^{35}$ space determined 
by plasma disappearance over $3 \mathrm{hr}(6,29)$. Total body water (TBW) and the dry weight of both kidneys (DKW) were determined by drying the animal carcass and the kidneys in an oven at $100^{\circ} \mathrm{C}$ until a stable weight was recorded on 3 consecutive days. The renal clearance of inulin (Cin) was determined by a standard infusion technique in $0.25 \% \mathrm{NaCl}$ solution at $0.051 \mathrm{ml} / \mathrm{kg} / \mathrm{min}$. After an equilibration period of $45 \mathrm{~min}$, four 30 - $\mathrm{min}$ urine collections were made, and a blood sample was drawn at the midpoint of each period. Each sample of urine and blood was analyzed for inulin (diphenylamine) (43), for sodium and potassium (flame spectrophotometer), and for phosphate (phosphorus test; Hycel, Inc., Houston, TX). The renal handling of each substance represented the average value from four collection periods.

Gentamicin concentrations in plasma and urine of the first collection period were determined; gentamicin clearance $\left(\mathrm{C}_{\mathrm{G}}\right)$ was calculated. In gentamicin puppies, coronal sections of the left renal cortex were made in duplicate for gentamicin assay, separated at the corticomedullary junction, and divided into approximate halves to represent outer and inner cortices. The entire cortex of each kidney was separated from the medulla by careful dissection; the wet and dry weights of each were determined. Tissue specimens of renal medulla and papilla, cerebral cortex, myocardium, lung, liver, jejunum, and ileum were obtained for gentamicin assay from one gentamicin puppy at each age of study.

Sections of the superficial cortex with capsule and juxtamedullary cortex with medulla were processed for microscopic examination for every animal. Tissue was fixed by immersion in $5 \%$ glutaraldehyde, postfixed in $1 \%$ osmium tetroxide, and embedded in Spurr; $1-\mu \mathrm{m}$-thick sections were examined under a Philips 200 transmission electron microscope. Additional tissue for light microscopy was fixed in Dubosq-Brazil's fluid for 3 to $4 \mathrm{hr}$, postfixed in $10 \%$ neutral buffered formalin, and embedded in paraffin. Sections 4 to $6 \mu \mathrm{m}$ thick were stained with hematoxylin-eosin, periodic acid-Schiff, periodic acid-methenamine silver, and Masson trichrome reagents.

\section{UNPAIRED STUDIES}

In other experiments, unpaired puppies were treated with gentamicin or saline from birth according to the same protocol given for paired experiments, and an equal number in each group were studied at either $10(n=3), 20(n=4)$, or $30(n=4)$ days of age to define further the pharmacokinetics of gentamicin, the distribution of gentamicin within the renal cortex, and the differences in kidney weight noted in paired experiments. After the IM injections of gentamicin $(3.75 \mathrm{mg} / \mathrm{kg})$ in both treated and control animals, plasma samples were drawn at 45, 120, 180, and $240 \mathrm{~min}$; the half-life of gentamicin in plasma $\left(t_{1 / 2}\right)$ was determined from the linear $\beta$ phase of an elimination curve (39). $P_{C r}$ was measured at birth and on the day of study. Each puppy was sacrificed by an anesthetic overdose; tissue samples from experimental animals were obtained for gentamicin assay from renal cortex trisected arbitrarily to represent outer, middle, and inner cortices. Both kidneys in every animal were dried, weighed, and analyzed for total protein (25) and DNA contents (10).

\section{COMPARISON STUDIES}

To compare observations made in neonates with older puppies and adults, two 30-day-old puppies and two adult animals were given gentamicin $(7.5 \mathrm{mg} / \mathrm{kg} / \mathrm{day})$ in two divided $\mathrm{IM}$ injections for 30 and 10 days, respectively. $t_{1 / 2}$ and $P_{C r}$ were determined in the puppies at weekly intervals during treatment and for an additional 30 days after gentamicin had been discontinued. The kidneys were removed, the renal cortex was trisected, and tissue concentrations of gentamicin were measured. $P_{C_{r}}$ was measured in the adults before and at 5 and 10 days during therapy.

\section{GENTAMICIN ASSAY}

Each weighed tissue sample was placed in a Duall tissue grinder (T. M. Kontes Glass Co., Vineland, NY) and macerated in $4 \mathrm{ml}$ of a $0.01 \mathrm{M}$ phosphate buffer solution ( $\mathrm{pH} 7.4$ ), and the homogenate was transferred to a $20 \mathrm{ml}$ glass vial in which the volume of the homogenate was increased to $6.0 \mathrm{ml}$ with $0.9 \% \mathrm{NaCl}$ solution. Pancreatin (Grand Island Biological Company, Grand Island, $\mathrm{NY})$ was added $(0.4 \mathrm{ml})$ to each vial and incubated at $37^{\circ} \mathrm{C}$ overnight. The action of pancreatin was terminated by placing the homogenate in a boiling water bath for $5 \mathrm{~min}$. Gentamicin concentrations in tissue homogenates, plasma, and urine were assayed by the RIANEN gentamicin system (New England Nuclear, North Bellerica, MA). Tissue concentrations of gentamicin were expressed per $\mathrm{g}$ of wet tissue and plasma concentrations in $\mu \mathrm{g} / \mathrm{ml}$. Validation of this method included: (1) examining the sediment of centrifuged tissue homogenate after pancreatin digestion and. after histologic staining, no cellular elements were found; (2) assaying duplicate plasma samples from control animals, to which known quantities of gentamicin had been added. Pancreatin was added to one of the samples, and no difference in gentamicin concentrations was observed between the samples; and (3) comparing this method to repeated macerations in phosphate buffer and finding it to be more efficient in extracting gentamicin from tissue.

Methods of statistical analysis included the Student $t$ test for paired and unpaired data to test for differences between groups at each age of study and correlation analysis (41) to compare observed changes with either the age of the animal or duration of therapy.

\section{RESULTS}

\section{PAIRED STUDIES}

A summary of results from paired experiments is given in Table 1. TBW (y $=780.06-2.24 \mathrm{x} ; r=-0.671 ; P<0.001)$ and ECFV $(\mathrm{y}=313.62-0.866 \mathrm{x} ; r=-0.663 ; P<0.001)$ decreased in all animals with postnatal age; no differences were noted between paired animals.

Cin $(\mathrm{ml} / \mathrm{min})$ increased with age in control $(\mathrm{y}=0.17 \mathrm{x}+1.35$; $r=0.552 ; P<0.05)$ but not in gentamicin puppies $(\mathrm{y}=0.076 \mathrm{x}$ $+2.67 ; r=0.304: \mathrm{P}>0.2$ ). Cin was lower in gentamicin puppies both at 20 and 30 days, but the differences were not statistically significant $(P<0.2)$. Cin $(\mathrm{ml} / \mathrm{min} / \mathrm{g} \mathrm{DKW})$ increased with age in control $(\mathrm{y}=0.043 \mathrm{x}+1.44 ; r=0.388 ; 0.1>P>0.05)$, but decreased with age $(\mathrm{y}=2.23-0.027 \mathrm{x} ; r=-0.30 ; P>0.2)$ in gentamicin puppies, where differences between paired animals were statistically significant at 20 days $(P<0.05)$ and approached significance at 30 days $(0.1>\mathrm{P}>0.05)$.

Fractional excretion of sodium and plasma potassium concentrations were not different between the paired animals at any age. Tubular reabsorption of phosphate did not change with age in control animals $(\mathrm{y}=0.258 \mathrm{x}+77.28 ; r=0.106 ; P>0.2)$ but decreased with age in the gentamicin animals $(y=105.31-$ $1.501 \mathrm{x} ; r=-0.674 ; P<0.001)$; differences between paired animals at 30 days were significant $(P<0.02)$. Plasma phosphate concentrations between paired animals were not statistically different.

DKW increased with postnatal age in control $(y=0.045 x+$ $1.11 ; r=0.649 ; P<0.01)$ and gentamicin $(\mathrm{y}=0.095 \mathrm{x}+0.67 ; r$ $=0.860 ; P<0.01)$ puppies. Both wet and dry kidney weights of gentamicin puppies were significantly greater than controls at 20 $(P<0.05)$ and 30 days $(P<0.01)$; kidney water was not different between animal pairs.

Neither peak $(\mathrm{r}=-0.055 ; P>0.8)$ nor trough $(r=0.049 ; P>$ $0.8) P_{G}$ increased with duration of therapy in gentamicin puppies (Table 2). Peak concentrations of $\mathrm{P}_{\mathrm{G}}$ on the day of study correlated neither with TBW $(\mathrm{y}=14.215-0.0128 \mathrm{x} ; r=0.29 ; P>0.2)$ nor with ECFV ( $\mathrm{y}=0.0031 \mathrm{x}+4.023 ; r=0.092 ; P>0.7)$. $\mathrm{C}_{\mathrm{C}}$ increased with $C$ in in all treated puppies $(r=0.452 ; P<0.05)$ (Table 2; Fig. 1). Mean values for $\mathrm{C}_{\mathrm{i}} / \mathrm{C}$ in were $0.74,0.60$, and 0.67 at 10,20 , and 30 days. Tissue levels of gentamicin in outer and inner cortices of experimental animals were compared at three ages of study (Table 2). No difference in gentamicin concentrations between 
Table 1. Summary of data from paired experiments in puppies

\begin{tabular}{|c|c|c|c|c|c|c|c|c|c|c|c|c|}
\hline \multirow[b]{2}{*}{$\begin{array}{c}\text { Age } \\
\text { (days) }\end{array}$} & \multirow[b]{2}{*}{$\begin{array}{c}\text { Pairs } \\
(n)\end{array}$} & \multirow[b]{2}{*}{ Group } & \multirow{2}{*}{$\begin{array}{c}\text { Birth } \\
\text { wt } \\
(\mathrm{g}) \\
\end{array}$} & \multirow{2}{*}{$\begin{array}{c}\text { Study } \\
\text { wt } \\
(\mathrm{g})\end{array}$} & \multirow[b]{2}{*}{$\begin{array}{c}\text { TBW } \\
(\mathrm{ml} / \mathrm{kg}) \\
\end{array}$} & \multirow[b]{2}{*}{$\begin{array}{c}\text { ECFV } \\
(\mathrm{ml} / \mathrm{kg})\end{array}$} & \multicolumn{2}{|c|}{ Clearance of inulin } & \multirow[b]{2}{*}{$\begin{array}{l}\text { TRP } \\
(\%)\end{array}$} & \multirow[b]{2}{*}{$\begin{array}{c}F E_{\mathrm{Na}^{\prime}}{ }^{1} \\
(\%)\end{array}$} & \multirow{2}{*}{$\begin{array}{c}P_{K} \\
(m E Q / \\
\text { liter) }\end{array}$} & \multirow[b]{2}{*}{$\begin{array}{c}\text { DKW } \\
(\mathrm{g})\end{array}$} \\
\hline & & & & & & & $\mathrm{ml} / \mathrm{min}$ & $\begin{array}{c}\mathrm{ml} / \mathrm{min} / \mathrm{g} \\
\mathrm{DKW}\end{array}$ & & & & \\
\hline \multirow[t]{2}{*}{10} & 9 & Control & $421 \pm 22^{2}$ & $681 \pm 30$ & $764 \pm 7$ & $302 \pm 16$ & $2.6 \pm 0.3$ & $2.64 \pm 0.27^{3}$ & $77.2 \pm 10.7$ & $1.2 \pm 0.3$ & $3.5 \pm 0.3$ & $1.5 \pm 0.1$ \\
\hline & & $\begin{array}{l}\text { Gentami- } \\
\text { cin }\end{array}$ & $428 \pm 17$ & $720 \pm 42$ & $761 \pm 5$ & $301 \pm 14$ & $3.5 \pm 0.4$ & $2.05 \pm 0.23$ & $89.6 \pm 3.5$ & $0.6 \pm 0.2$ & $3.7 \pm 0.6$ & $1.7 \pm 0.1$ \\
\hline \multirow[t]{2}{*}{20} & 6 & Control & $362 \pm 21$ & $985 \pm 150^{3}$ & $727 \pm 11$ & $299 \pm 19$ & $5.7 \pm 0.9$ & $2.61 \pm 0.45^{3}$ & $92.7 \pm 3.0$ & $0.3 \pm 0.1$ & $2.9 \pm 0.2$ & $2.2 \pm 0.1^{3}$ \\
\hline & & $\begin{array}{l}\text { Gentami- } \\
\text { cin }\end{array}$ & $337 \pm 27$ & $857 \pm 148$ & $721 \pm 6$ & $284 \pm 17$ & $4.0 \pm 1.3$ & $1.48 \pm 0.42$ & $81.7 \pm 6.8$ & $0.9 \pm 0.4$ & $2.8 \pm 0.2$ & $2.5 \pm 0.2$ \\
\hline \multirow[t]{2}{*}{30} & 6 & Control & $368 \pm 17$ & $1152 \pm 118$ & $720 \pm 14$ & $276 \pm 18$ & $6.0 \pm 1.5$ & $2.58 \pm 0.55$ & $78.6 \pm 3.9^{4}$ & $1.2 \pm 0.5$ & $3.3 \pm 0.1$ & $2.4 \pm 0.3$ \\
\hline & & $\begin{array}{l}\text { Gentami- } \\
\text { cin }\end{array}$ & $378 \pm 14$ & $1148 \pm 47$ & $716 \pm 11$ & $291 \pm 22$ & $5.1 \pm 1.1$ & $1.50 \pm 0.30$ & $54.6 \pm 7.2$ & $1.3 \pm 0.5$ & $3.1 \pm 0.3$ & $3.5 \pm 0.3^{5}$ \\
\hline
\end{tabular}

\footnotetext{
${ }^{1} F E_{N_{H}}$, fractional excretion of sodium; $P_{K}$,plasma potassium concentration.

${ }^{2}$ Mean \pm S.E.

${ }^{3}$ Paired $t$ test, $P<0.005$

${ }^{4}$ Paired $t$ test, $P<0.02$.

${ }^{5}$ Paired $t$ test, $P<0.01$.
}

Table 2. Renal clearance and tissue accumulation of gentamicin from paired experiments

\begin{tabular}{|c|c|c|c|c|c|c|c|}
\hline \multirow[b]{2}{*}{$\begin{array}{l}\text { Age } \\
\text { (days) }\end{array}$} & \multirow[b]{2}{*}{$n$} & \multicolumn{2}{|c|}{ Plasma gentamicin } & \multirow{2}{*}{$\begin{array}{c}\text { Clearance of } \\
\text { gentamicin } \\
(\mathrm{ml} / \mathrm{min})\end{array}$} & \multicolumn{3}{|c|}{ Gentamicin in renal cortex } \\
\hline & & $\begin{array}{c}\text { Peak } \\
(\mu \mathrm{g} / \mathrm{ml})\end{array}$ & $\begin{array}{l}\text { Trough } \\
(\mu \mathrm{g} / \mathrm{ml})\end{array}$ & & $\begin{array}{l}\text { Outer } \\
(\mu \mathrm{g} / \mathrm{g})\end{array}$ & $\begin{array}{l}\text { Inner } \\
(\mu \mathrm{g} / \mathrm{g})\end{array}$ & $\begin{array}{c}\text { Ratio } \\
\text { outer/inner }\end{array}$ \\
\hline 10 & 9 & $\begin{array}{c}4.41 \pm 0.37^{1} \\
P=\mathrm{NS}\end{array}$ & $\begin{array}{c}0.22 \pm 0.07 \\
P=\mathrm{NS}\end{array}$ & $2.6 \pm 0.6$ & $\begin{array}{c}91.1 \pm 23.1 \\
P<0.005\end{array}$ & $\begin{array}{c}154.6 \pm 31.2 \\
P=\mathrm{NS}\end{array}$ & $\begin{array}{c}0.67 \pm 0.13 \\
P<0.001\end{array}$ \\
\hline 20 & 6 & $\begin{array}{c}4.62 \pm 0.98 \\
P=\mathrm{NS}\end{array}$ & $\begin{array}{c}0.35 \pm 0.14 \\
P=\mathrm{NS}\end{array}$ & $2.4 \pm 0.8$ & $\begin{array}{c}752.3 \pm 233.5^{2} \\
P=\mathrm{NS}\end{array}$ & $\begin{array}{c}486.0 \pm 186.1 \\
P=\mathrm{NS}\end{array}$ & $\begin{array}{c}1.84 \pm 0.27 \\
P=\mathrm{NS}\end{array}$ \\
\hline 30 & 6 & $4.92 \pm 0.41$ & $0.21 \pm 0.05$ & $3.4 \pm 1.0$ & $811.5 \pm 178.0^{2}$ & $367.2 \pm 75.4$ & $2.84 \pm 0.81$ \\
\hline
\end{tabular}

\footnotetext{
${ }^{1}$ Mean \pm S. E

' $t$ test, $P<0.05$
}

cortical areas was observed at 10 days. Between 10 and 20 days, gentamicin levels in outer cortical tissue increased significantly $(P$ $<0.005$ ), but the increase in the inner cortical concentrations was not statistically significant. At 30 days, tissue gentamicin concentrations of the outer cortex were significantly higher than inner cortex $(P<0.05)$. The ratio of outer/inner cortical gentamicin concentrations increased significantly with length of drug administration $(\mathrm{y}=0.0894 \mathrm{x}+0.0746 ; r=0.579 ; P<0.01)$. Gentamicin accumulation in body tissues, presented in Table 3 for one puppy at each age of study, increased with duration of gentamicin therapy in every organ examined. Gentamicin concentrations in renal medulla and papilla were much higher than in body tissues other than kidney, but accumulation in renal cortex was 80 -fold greater than liver and 900 -fold greater than brain.

At birth, $\mathrm{P}_{\mathrm{Cr}}$ in control puppies was $0.70 \pm 0.06 \mathrm{mg} / \mathrm{dl}(n=21)$ and was not different from maternal values of $0.79 \pm 0.24 \mathrm{mg} / \mathrm{dl}$ $(n=9)$. After birth, $\mathrm{P}_{\mathrm{Cr}}$ decreased significantly during the first month of life $(\mathrm{y}=0.6833-0.009 \mathrm{x} ; r=-0.370 ; P<0.02)$. $\mathrm{P}_{\mathrm{Cr}}$ in gentamicin puppies continued to decrease like the controls even when tubular damage was marked at 20 and 30 days (Table 5). Examination of the urine for numbers of red and white blood cells and casts for osmolarity, glucose, and protein concentrations revealed no differences between paired animals.

The superficial cortex of the kidneys at 10 days indicated that in control and gentamicin animals, tubular epithelium was immature with little or no lumen identifiable; lysosomal changes were not noted in tubular cells (Fig. 2a). Proximal tubular cells in the juxtamedullary cortex of control kidneys had normal-appearing mitochondria and scattered small lysosomes, whereas the gentamicin kidneys had an increased number and enlargement of lysosomes that are referred to as cytosegresomes; a few had myelin figures or myeloid bodies (Fig. $2 b$ ).
The superficial cortex of gentamicin animals at 20 days (Fig. $2 c$ ) revealed even more pronounced lysosomal changes than the juxtamedullary cortex in the gentamicin animals at 10 days. In addition to focal losses of luminal microvilli, cellular infiltrates, and degeneration of tubular epithelium in the juxtamedullary cortex of gentamicin kidneys (Fig. 2d), there was increased interstitial collagen deposition compared to the same area of cortex in control kidneys. By 30 days of treatment, there was sloughing of the degenerated tubular epithelial cells of both the superficial (Fig. 2e) and juxtamedullary (Fig. 2f) cortices, many of which remained intact within the debris of the tubular lumen and still contained giant cytosegresomes and evidence of regenerating epithelium. The increase in interstitial collagen was even more pronounced than noted in the cortex of gentamicin kidneys at 20 days.

\section{UNPAIRED EXPERIMENTS}

Peak and trough $P_{G}$ and $P_{C r}$ were not different between treated and control groups at any age (Table 5). $t_{1 / 2}$ in control animals decreased with postnatal age $(\mathrm{y}=99.13-2.1167 \mathrm{x} ; r=0.907 ; P$ $<0.001)$. No statistical difference in $t_{1 / 2}$ between gentamicin puppies and controls was observed at either 10 or 20 days of age, but $t_{1 / 2}$ in gentamicin puppies at 30 days was significantly longer than control values $(P<0.05)$, and longer than either gentamicin $(P<0.01)$ or control $(P<0.02)$ puppies at 20 days.

In the trisected renal cortex of gentamicin puppies, there was no difference in concentrations of gentamicin among the different areas at 10 days (Table 5). The increase in tissue gentamicin concentrations in the inner cortex between 10 and 20 days was significant $(P<0.005)$; no significant increase was noted between 20 and 30 days. Gentamicin concentration in the middle cortex 

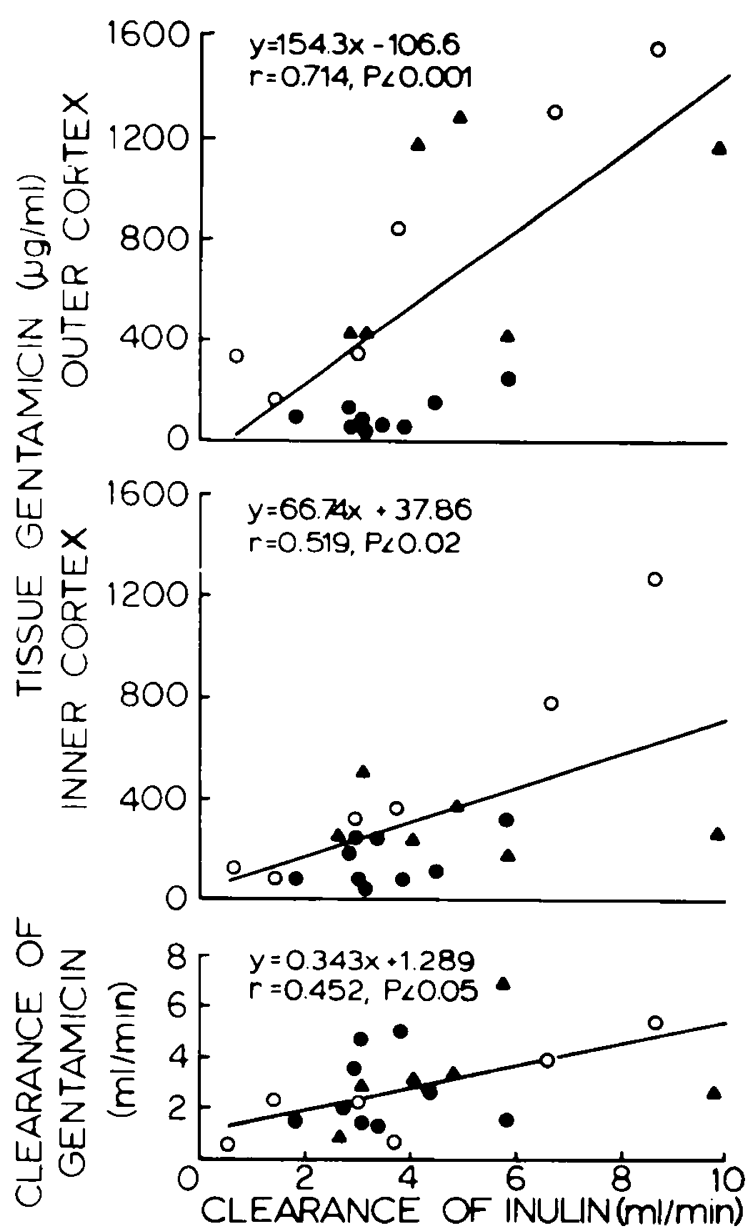

Fig. 1. Clearance of inulin in gentamicin puppies from paired experiments is compared to the clearance of gentamicin and to the tissue concentrations of gentamicin in inner and outer renal cortices. Puppies were studied at 10 days $(\Theta), 20$ days $(O)$, or 30 days $(\Delta)$ of age.

increased with age $(\mathrm{y}=33.07 \mathrm{x}-191.33 ; r=0.831 ; P<0.001)$, but a statistical difference was not observed between successive age groups; the difference in tissue concentrations between 10 and 30 days, however, was statistically significant $(P<0.001)$. Gentamicin concentrations in outer cortex did not increase significantly between 10 and 20 days, but the increase between 20 and 30 days was significant $(P<0.001)$.

Both wet and dry kidney weights ( $\mathrm{g} / \mathrm{kg}$ body weight) increased with postnatal age in control and gentamicin puppies; however, DKW was greater in gentamicin animals at every age (Table 5). Differences in DKW could not be accounted for by statistically significant increases in either DNA or total protein; however, ratios of DNA/total protein (TP) were similar between groups at 10 days $(0.079 \pm 0.011$ versus $0.080 \pm 0.011$; mean \pm S.E. $)$ and were higher in gentamicin puppies at 20 days $(0.044 \pm 0.006$ versus $0.065 \pm 0.009 ; 0.1>P>0.05)$ and at 30 days $(0.042 \pm 0.07$ versus $0.055 \pm 0.009 ; 0.1>P>0.05$ ).

\section{COMPARISON STUDIES}

The results of comparison experiments in older puppies and adults are compared to that from newborn puppies in Figure 3. In adult animals, $P_{C r}$ increased abruptly between 5 and 10 days of initiating gentamicin therapy. In puppies given gentamicin from 30 days of age, $\mathrm{P}_{\mathrm{Cr}}$ and $t_{1 / 2}$ were increased at 10 days and continued to increase with gentamicin therapy. Between 20 and 30 days of therapy, $t_{1 / 2}$ was $>500 \mathrm{~min}$ in each puppy. During 30 days after discontinuation of gentamicin, $P_{C r}$ returned to control values in both puppies as $t_{1 / 2}$ decreased to $235 \mathrm{~min}$ in one puppy and 150 $\min$ in the other when tissue concentrations of gentamicin in the outer/middle/inner cortex were $345 / 531 / 339 \mu \mathrm{g} / \mathrm{g}$ and $642 / 650 /$ $524 \mu \mathrm{g} / \mathrm{g}$.

\section{DISCUSSION}

Gentamicin nephrotoxicity has been demonstrated to follow an almost predictable clinical course in adult human and animal studies $(1,45)$. The accumulation of gentamicin in the kidney has been demonstrated to occur for the most part across apical and, perhaps to a lesser extent, basolateral membranes of proximal tubular cells $(22,33,40)$. After reabsorption, gentamicin has not been demonstrated to be transported out of the tubular cell. Both intracellular concentrations of gentamicin in the renal cortex and the severity of pathologic and functional changes in the kidney, suggested by previous studies $(14,16,17,20,24,27,44)$, increase with continued administration of the drug; a direct relationship is implied.

Factors reported to enhance gentamicin nephrotoxicity include dehydration (13), sodium (8), or potassium (11) depletion; acidosis (21): diuretic administration (1); and concomitant use of cephalosporins (9). Sick newborn infants for whom gentamicin is prescribed commonly exhibit one or more factors which should predispose them towards gentamicin nephrotoxicity; however, $\mathrm{P}_{\mathrm{Cr}}$ has not been reported to increase in neonates during 7 to 10 days of gentamicin therapy. The neonate is said, therefore, to be "more tolerant" than the adult to the nephrotoxic effects of gentamicin. Neither electron microscopic studies of the renal tubular epithelium nor tissue concentrations of gentamicin in neonates given gentamicin has been reported, but differences in basic mechanisms for gentamicin handling by neonatal and adult kidneys would be unlikely. Conflicting observations between age groups would perhaps be explained better by physiologic or morphologic differences during renal development.

The pharmacokinetics and tissue accumulation of gentamicin in the neonatal puppy (Tables 2 and 5) were similar to that described for the adult dog $(1,12,44)$. Peak levels of $P_{G}$ were not related to TBW or ECFV in the puppy as has been speculated for, but not measured in, the human (38). $t_{1 / 2}$ decreased with postnatal age in control puppies in a manner similar to human infants (30, $32,39)$ and at 30 days was similar to that reported for adult rats (26) and children (39). $t_{1 / 2}$ and $P_{C r}$ increased with the duration of therapy in gentamicin puppies treated from 30 days of age. Although most body tissues in the puppy accumulated small quantities of gentamicin (Table 3$)$ similar to human adults $(2,14$, $36,44)$, the most significant tissue accumulation occurred in the renal cortex, which along with that portion of filtered gentamicin

Table 3. Representative concentrations of gentamicin in plasma and body tissues of puppies treated from birth ${ }^{1}$

\begin{tabular}{lccc}
\hline & \multicolumn{3}{c}{ Age (days) } \\
\cline { 2 - 4 } & 10 & 20 & 30 \\
\hline Plasma $(\mu \mathrm{g} / \mathrm{ml})$ & & & \\
$\quad$ peak & 4.3 & 6.4 & 3.1 \\
trough & 0.1 & 0.9 & 0.8 \\
& & & \\
Brain $(\mu \mathrm{g} / \mathrm{g})$ & 0.4 & 0.8 & 0.8 \\
Heart $(\mu \mathrm{g} / \mathrm{g})$ & 1.1 & 1.1 & 1.9 \\
Lung $(\mu \mathrm{g} / \mathrm{g})$ & 1.8 & 2.3 & 6.5 \\
Liver $(\mu \mathrm{g} / \mathrm{g})$ & 1.1 & 8.7 & 9.0 \\
Jejunum $(\mu \mathrm{g} / \mathrm{g})$ & 1.2 & 1.1 & 3.7 \\
lleum $(\mu \mathrm{g} / \mathrm{g})$ & 2.1 & 1.5 & 4.0 \\
Kidney $(\mu \mathrm{g} / \mathrm{g})$ & & & \\
Outer cortex & 116 & 350 & 717 \\
Middle cortex & 121 & 321 & 637 \\
Juxtamedullary cortex & 190 & 477 & 454 \\
Medulla & 13.6 & 31.8 & 50 \\
Papilla & 6.9 & 30.4 & 40 \\
\hline
\end{tabular}

' Five $\mathrm{mg} / \mathrm{kg} /$ day $\mathrm{IM}$ for 7 days, then $7.5 \mathrm{mg} / \mathrm{kg} /$ day. 

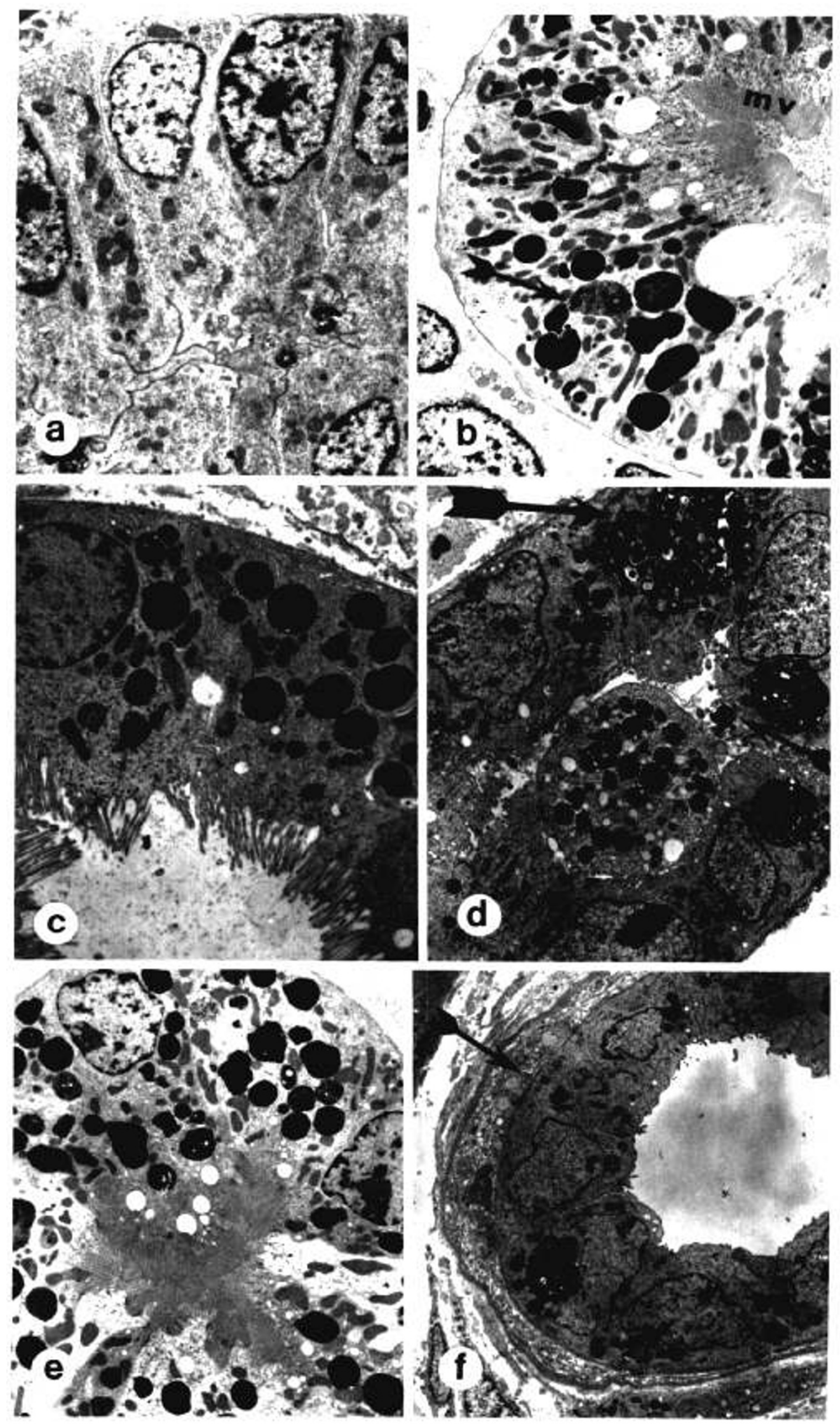

Fig. 2. $a$ to $f$, electronmicrographs of representative sections of proximal tubular cells from superficial (upper) and juxtamedullary cortex (lower) of puppies given gentamicin from birth at 10,20, and 30 days (left to right); $a$, superficial cortex at 10 days (upper left) showing an immature tubule with inconspicuous cytoplasmic lysosomes. $\times 7000 ; b$, juxtamedullary cortex at 10 days (lower left) showing intact luminal microvilli (mv) and conspicuous, variably sized cytoplasmic lysosomes of heterogeneous internal structure (arrow). $\times 4300 ; c$, superficial cortex at 20 days (upper center) showing changes similar to those described in $b . \times 5520 ; d$, juxtamedullary cortex at 20 days (lower center) showing swollen cytoplasm, giant cytoplasmic cytosegresomes (large arrow) and disrupted luminal microvilli (small arrow). $\times 4300$; $e$, superficial cortex at 30 days (upper right) showing changes similar to those described in $b . \times 4300 ; f$, juxtamedullary cortex at 30 days (lower right) showing regenerative epithelial lining (re) and thickened basement membrane with entrapped necrotic cellular debris (arrow). $\times 3360$. 
excreted into urine, appeared to determine the $t_{1 / 2}$ and account for a major portion of the second in the two-compartment pharmacokinetics proposed for gentamicin. The range of mean ratios of $\mathrm{C}_{\mathrm{i}} / \mathrm{Cin}$ in the puppies was 0.60 to 0.74 ; all were less than the reported adult value of 0.8 (12). Puppies, therefore, reabsorbed a greater portion of filtered gentamicin than the adult. Moreover, between 10 and 20 days, $C_{i} / C$ in decreased when concentrations of gentamicin in the renal cortex were significantly increased. The persistence of gentamicin in renal tissue. however, appeared to be longer than the $109 \mathrm{hr}$ measured in the rat (26) in that concentrations in the renal cortex of older puppies 30 days after the final dose of gentamicin were only slightly less than those measured at the end of 30 days therapy in neonatal puppies.

Indicators of clinically impaired nephron function reported for adults given gentamicin, such as proteinuria $(23,40)$, glucosuria (17), and cylinduria (35), were not observed in gentamicin puppies even at 20 or 30 days when pathologic injury to renal tubular cells was marked (Table 4). Although maximal renal concentrating ability was not examined, initial urine osmolarities, unlike adult rats $(16,27)$, were not different between control and gentamicin puppies. The failure to observe a rise in $\mathrm{P}_{\mathrm{Cr}}$ during gentamicin therapy in the puppy was not surprising because, just as in the human infant at birth, $P_{C_{r}}$ was not different from that of the mother (37), and after birth, $P_{C r}$ in control puppies (Fig. 3) decreased significantly during the first month of life, just as has been reported for human premature infants (42). One could not expect a rise in $P_{{ } r}$, therefore, to reflect a decrease in GFR during a time that $P_{C_{r}}$ is normally decreasing and GFR is normally increasing (Table 1). Moreover, the same dose of gentamicin given older puppies and adult dogs resulted in prompt increases in $\mathrm{P}_{\mathrm{Cr}}$ within 10 days (Fig. 3).

Gentamicin accumulation during the first 10 days of therapy in the puppy kidney (Table 5) occurred more in the inner cortex where the first pathologic changes were observed; no pathologic evidence of gentamicin toxicity was observed in the outer cortex at 10 days. After 10 days, however, further gentamicin accumulation occurred in the outer cortex, evidenced not only by increased tissue concentrations of gentamicin but also by an increase in ratios of gentamicin concentrations in the outer/inner cortex. Pathologic evidence of gentamicin nephrotoxicity also occurred in a centrifugal pattern.

Renal blood flow (RBF) (5) and GFR (4) are low at birth in the puppy and do not increase appreciably until redistribution of RBF occurs during the second wk of life, when further increments in GFR reflect increases in superficial nephron filtration (19). Although RBF has not been reported in normal human infants, a pattern of change in GFR for the human premature infant around $34 \mathrm{wk}$ gestational age is similar to that of the puppy $(3,4)$. These physiologic changes in RBF and GFR in different species appear to occur at a time during renal development when glomerulogenesis has been completed $(18,34)$.

The increase in and centrifugal redistribution of $R B F$ would have resulted in increased delivery of gentamicin to more superficial cortical nephrons, compared to inner cortical nephrons; therefore, outer cortical nephrons of the puppy were protected from gentamicin accumulation before that time. Measurements of RBF were not made during the paired experiments, but a direct relationship was observed between the increase in GFR and

Table 4. Comparison of urine composition and plasma creatinine concentrations in puppies from paired experiments

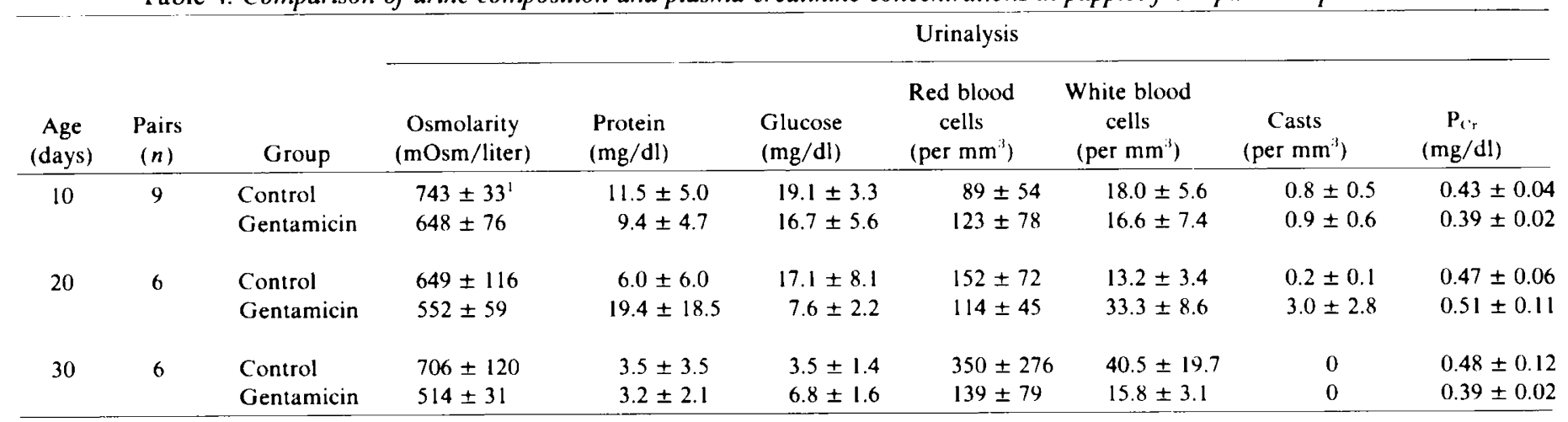

\footnotetext{
'Mean \pm S.E.
}

Table 5. Gentamicin pharmacokinetics in puppies from unpaired experiments

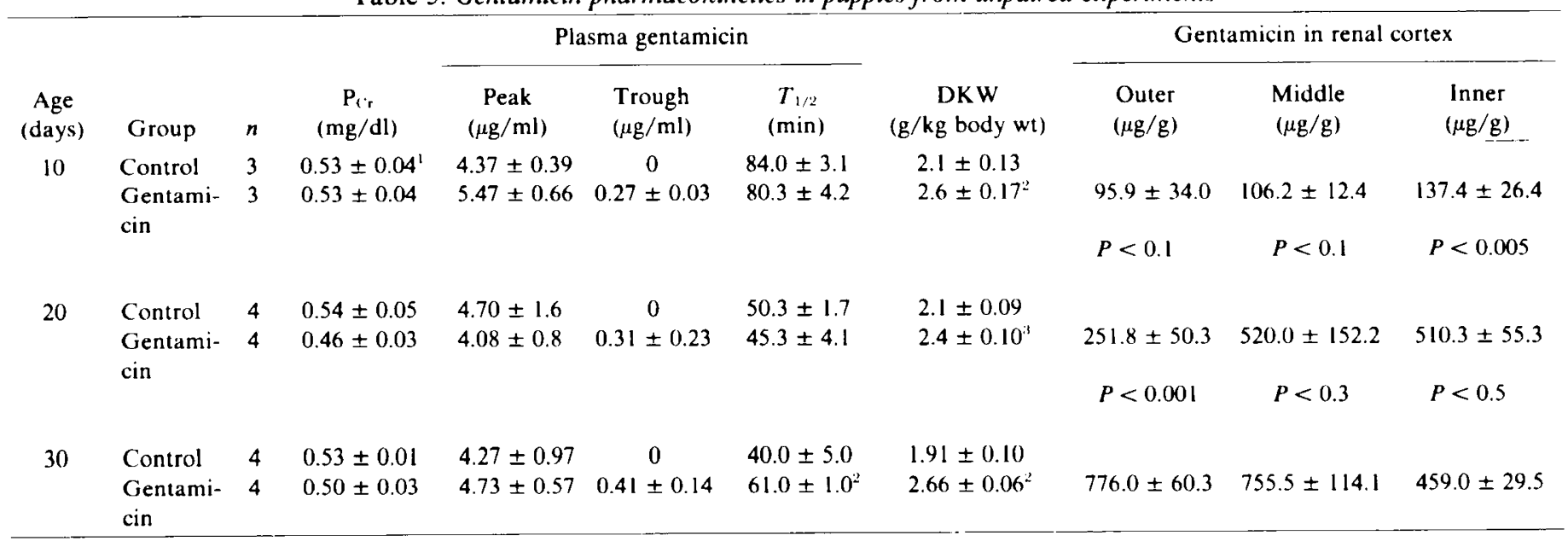

\footnotetext{
${ }^{1}$ Mean \pm S.E.

${ }^{2} t$ test, $P<0.05$.

${ }^{3} t$ test, $P<0.001$
} 


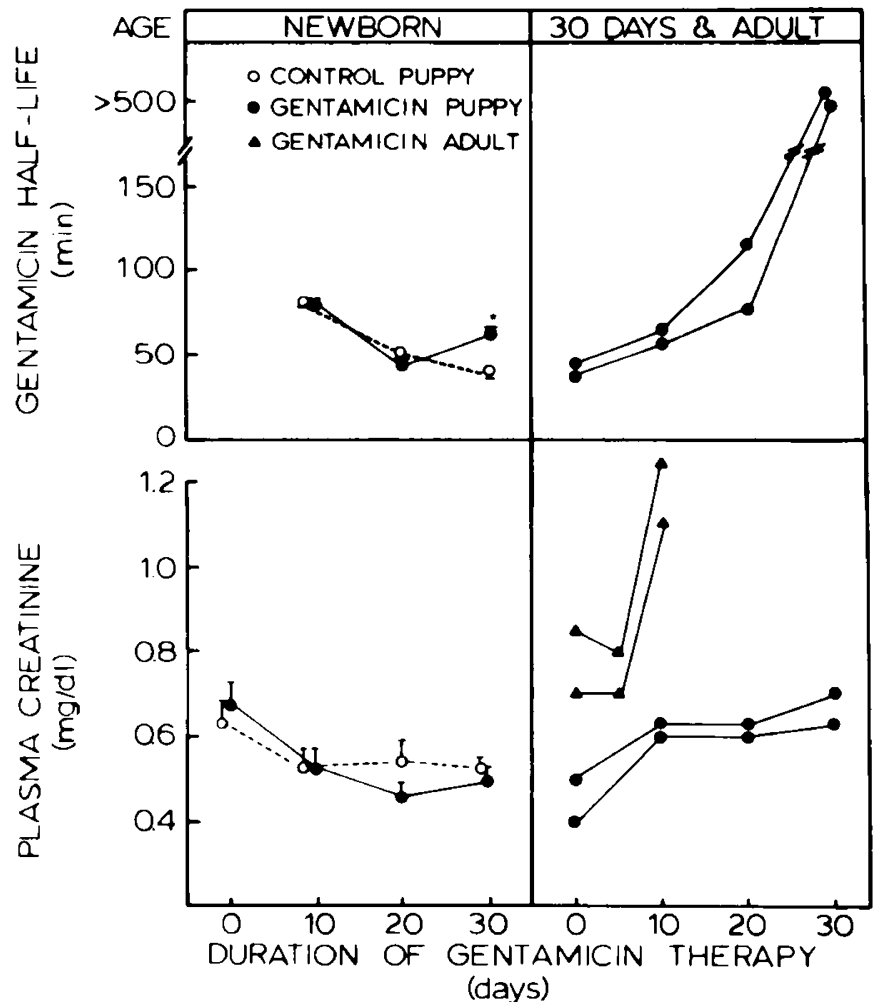

Fig. 3. Changes in plasma creatinine concentration $\left(P_{(r)}\right)$ and gentamicin half-life in plasma $\left(t_{1 / 2}\right)$ are compared to the duration of gentamicin therapy. Results (mean \pm S.E.) in equal numbers of control $(O)$ and gentamicin (O) puppies treated from birth in unpaired experiments $(n=$ 3,4 , and 4 at 10,20, and 30 days) are shown in the left panel and include $P_{(} \cdot r$ at birth in the 11 puppies studied. ${ }^{*}$, difference in $t_{1 / 2}$ between groups $(P<0.05), t$ test $)$. Comparison data obtained in older animals are shown in the right panel and include $\mathrm{P}_{\mathrm{Cr}}$ and $t_{1 / 2}$ in two puppies treated from 30 days of age $\left(\mathbf{)}\right.$ ) and $P_{C r}$ only in two adults $(\mathbf{\Delta})$.

gentamicin accumulation in both the outer and inner renal cortices (Fig. 1). Moreover, gentamicin concentrations in the trisected renal cortices (Fig. 3 ) very nearly reproduced the intrarenal distribution of radiolabelled microspheres (31) or ${ }^{133}$ Xenon (5) during the first month of life in the puppy. In the adult kidney, gentamicin accumulation is more or less uniform throughout the cortex, and no further accumulation was observed in the rat kidney after the fifth day of treatment (27). In the puppies, mean values of gentamicin concentration in the inner cortex actually decreased between 20 and 30 days which could have resulted from regeneration of tubular epithelium, from sloughing and excretion of necrotic tubular cells or from increased interstitial collagen deposition; each explanation was supported by pathologic findings.

Phosphate is reabsorbed primarily in the proximal tubule and, in gentamicin puppies, tubular reabsorption of phosphate decreased as proximal tubular damage increased with continued gentamicin administration. The decrease in GFR associated with gentamicin nephrotoxicity has been reported to reflect changes in filtration coefficients for most glomerular capillaries (7). During canine renal development, nephrons contribute to overall renal function in a centrifugal pattern, and the last ones to begin filtering are those in the superficial cortex (19). If renal accumulation depends upon reabsorption of the gentamicin filtered, nonfiltering nephrons would be spared the nephrotoxic effects of gentamicin. Failure to demonstrate a difference in GFR between paired puppies after 30 days of gentamicin administration, therefore, might have been anticipated. There was suggestive evidence that differences would have become apparent in time because GFR did not increase significantly with postnatal age in gentamicin puppies as it did in controls. A more pronounced impairment of GFR may have been offset by recovery of renal function, such as observed in adult rats, even while gentamicin therapy was contin- ued (16). The increased ratios of DNA/TP at 20 days and the histologic evidence of tubular cell regeneration in gentamicin kidneys at 20 and 30 days would support such an explanation.

The results of these studies confirm that gentamicin nephrotoxicity did occur in the neonatal puppy even after 7 to 10 days of therapy and that the severity of the pathologic damage in the neonate was related directly to the accumulation of gentamicin in the renal cortex. Moreover, clinical indicators of gentamicin nephrotoxicity suggested for the adult did not serve a similar purpose in the newborn animal. The relative tolerance of the neonatal canine kidney to the toxic effects of gentamicin could be attributed to the distribution of RBF predominantly to the juxtamedullary cortex at birth, which spared more superficial nephrons from gentamicin accumulation until RBF was redistributed and filtration began in these nephrons after the first wk of life.

\section{REFERENCES AND NOTES}

1. Adelman, R. D., Spangler, W. L., Beasom, F., Ishizaki, G., and Conzelman, G. M.: Furosemide enhancement of experimental gentamicin nephrotoxicity: a comparison of functional and morphological changes with urinary enzyme activities. J. Infect. Dis., 140: 342 (1979).

2. Alfthan, O., Renkonen, O. V., and Sivonen, A.: Concentration of gentamicin in serum, urine and urogenital tissue in man. Acta Pathol. Microbiol. Scand. Sect. B. Microbiol. Immunol. Suppl. 241, 81: 92 (1973).

3. Arant. B. S., Jr.: Developmental patterns of renal functional maturation compared in the human neonate. J. Pediatr.. 92: 705 (1978).

4. Arant. B. S., Jr.: Glomerulotubular balance following saline loading in the developing canine kidney. Am. J. Physiol., 235: F417 (1978).

5. Aschinberg. L. C., Goldsmith. D. I., Olbing, H., Spitzer, A., Edelmann, C. M., Jr., and Blaufox, M. D.: Neonatal changes in renal blood flow distribution in puppies. Am. J. Physiol., 228: 1453 (1975).

6. Bauer, J. H., Burt, R. W., Whang, R., and Grim, C. E.: Simultaneous determination of extracellular fluid and total body water. I. J. Lab. Clin. Med.. 86: 1003 (1975)

7. Baylis, C., Rennke, H. R., and Brenner, B. M.: Mechanisms of the defect in glomerular ultrafiltration associated with gentamicin administration. Kidney Int., 12: 344 ( 1977).

8. Bennett, W. M., Hartnett, M.. Gilbert, D.. Houghton, D., and Porter, G.: Effect of sodium intake on gentamicin nephrotoxicity in the rat. Proc. Soc. Exp. Biol. Med.. 151: 736 (1976).

9. Bobrow, S. N., Jaffe, E., and Young, R. C.: Anuria and acute tubular necrosis associated with gentamicin and cephalothin. J. Am. Med. Assoc., 222: 1546 (1972).

10. Brinker, K., Cronin, R., Bulger, R., Southern, P., and Henrich, W.: Potassium depletion: risk factor for and consequence of gentamicin nephrotoxicity. Kidney Int., 16: 849 (1979).

11. Burton, K.: Determination of DNA concentration with diphenylamine. Methods Enzymol., /2B: 163 (1968).

12. Chiu. P. H., Brown. A., Miller G., and Long. J. F.: Renal extraction of gentamicin in anesthetized dogs. Antimicrob. Agents Chemother., 10: 277 (1976).

13. Chiu, P. J. S., and Long. J. F.: Effect of hydration on gentamicin excretion and renal accumulation in furosemide-treated rats. Antimicrob. Agents Chemother., 14: 214 (1978)

14. Edwards, C. Q.. Smith, C. R., Baughman, K. L., Rogers, J. F., and Lietman, P. S.: Concentrations of gentamicin and amikacin in human kidneys. Antimicrob. Agents Chemother., 9: 925 (1976).

15. Fabre, J., Rudhardt. M., Blanchard, P., and Regamey, C.: Persistence of sisomicin and gentamicin in renal cortex and medulla compared with other organs and serum of rats. Kidney Int.. 10: 444 (1976).

16. Gilbert. D. N., Houghton, D. C.. Bennett, W. M., Plamp, C. E., Reger, K., and Porter. G. A.: Reversibility of gentamicin nephrotoxicity in rats: recovery during continuous drug administration. Proc. Soc. Exp. Biol. Med., 160: 99 (1979).

17. Ginsburg. D. S., Quintanilla, A. P.. and Levin, M.: Renal glycosuria due to gentamicin in rabbits. J. Infect. Dis., 134: 119 (1976).

18. Horster, M., Kemler, B. J.. and Valtin, H.: Intracortical distribution of number and volume of glomeruli during postnatal maturation in the dog. J. Clin. Invest., 50: 796, (1971).

19. Horster. M., and Valtin, H.: Postnatal development of renal function: micropuncture and clearance studies in the dog. J. Clin. Invest., 50: 779 (1971).

20. Houghton, D. C., Hartnett. M., Campbell-Boswell, M., Porter, G., and Bennett. W.: A light and electron microscopic analysis of gentamicin nephrotoxicity in rats. Am. J. Pathol., 82: 589 (1976).

21. Hsu. C. H., Kurtz, R. W., Easterling, R. E., and Weller, J. M.: Potentiation of gentamicin nephrotoxicity by metabolic acidosis. Proc. Soc. Exp. Biol. Med., 146: 894 (1974).

22. Just. M., Erdmann, G., and Habermann. E.: The renal handling of polybasic drugs. 1. Gentamicin and apoprotinin in intact animals. Naunyn-Schmeideberg's Arch. Pharmacol., 300: 57 (1977).

23. Kahn, T., and Stein, R. M.: Gentamicin and renal failure. Lancet, I: 498 (1972).

24. Kornguth, M. L., and Kunin, C. M.: Distribution of gentamicin and amikacin in rabbit tissues. Antibiot. Agents Chemother., 11: 974 (1977).

25. Lowry. O. H., Rosebrough, N. J., Farr, A. L., and Randall, R. J.: Protein measurement with the Folin phenol reagent. J. Biol. Chem., 193: 257 (1951). 
26. Luft. F. C.. and Kleit, S. A.: Renal parenchymal accumulation of aminoglycoside antibiotics. J. Infect. Dis., 130: 656 (1974).

27. Luft, F. C.. Patel, V., Yum, M. N., Patel, B., and Kleit, S. A.: Experimental aminoglycoside nephrotoxicity. J. Lab. Clin. Med.. 86: 213 (1976).

28. McCracken, G. H.. Jr.. and Jones, L. G.: Gentamicin in the neonatal period. Am. J. Dis. Child., /20: 524 (1970)

29. Murphy, B. Dossetor, J. B., and Beck, J. C.: Serial determinations of extracellular fluid volume using the radiosulfate space method. Can. J. Biochem. Physiol.. 41: $497(1963)$

30. Nelson, J. D., and McCracken, G. H., Jr.: Clinical pharmacology of carbenecillin and gentamicin in the neonate and comparative efficacy with ampicillin and gentamicin. Pediatrics, 52: 801 (1973).

31. Olbing. H., Blaufox, M. D., Aschinberg, L. C., Silkains, G. I., Bernstein, J., Spitzer, A., and Edelmann, C. M.. Jr.: Postnatal changes in renal blood flow distribution in puppies. J. Clin. Invest., 52: 2885 (1973).

32. Paisley, J. W., Smith. A. L., and Smith, D. H.: Gentamicin in newborn infants Am. J. Dis. Child., 126: 473 (1973).

33. Pastoriza-Munoz, E., Bowman, R. L., and Kaloyanides, G. J.: Renal tubular transport of gentamicin in the rat. Kidney Int., 16: 440 (1979).

34. Potter, E. L., and Thierstein, S. T.: Glomerular development in the kidney as an index of fetal maturity. J. Pediatr., 22: 695 (1943).

35. Schentag. J. J., Gengo, F. M., Plant, M. I., Danner, D., Mangrone. A., and Jusko, W. J.: Urinary casts as an indicator of renal tubular damage in patients receiving aminoglycosides. Antimicrob. Agents Chemother., 16: 468 (1979).

36. Schentag. J. J., and Jusko, W. J.: Renal clearance and tissue accumulation of gentamicin. Clin. Pharmacol. Ther., 22: 364 (1977).

37. Sertel, H., and Scopes, J.: Rates of creatinine clearance in babies less than one week of age. Arch. Dis. Child., 48: 717 (1973).

Copyright $\odot 1980$ International Pediatric Research Foundation, Inc.

$0031-3998 / 80 / 1411-1204 \$ 02.00 / 0$
38. Siber, G. R., Echeverria. P.. Smith, A. L., Paisley, J. W., and Smith, D. H.: Pharmacokinetics of gentamicin in children and adults. J. Infect. Dis., 132: 637 (1975)

39. Siber, G. R. Smith, A. L., and Levin, M. J.: Predictability of peak serum gentamicin concentration with dosage based on body surface area. J. Pediatr., 94: 135 (1979).

40. Silverblatt, F. J., and Kuehn. C.: Autoradiography of gentamicin uptake by the rat proximal tubule cell. Kidney Int., 15: 335 (1979).

41. Snedecor, G. W.: Statistical Methods, Ed. 5 (The Iowa State University Press, Ames, lowa, 1956)

42. Stonestreet, B. S., and Oh. W.: Plasma creatinine levels in low birth weight infants during the first three months of life. Pediatrics, 61: 788 (1978).

43. Walser, M., Davidson, D. G., and Orloff, J.: The renal clearance of alkali-stable inulin. J. Clin. Invest.. 34: 1520 (1955)

44. Whelton, A., Carter, G. G., Bryant, H. H., Fox, L., and Walker, W. G.: Therapeutic implications of gentamicin accumulation in severely diseased kidneys. Arch. Intern. Med., 136: 172 (1976).

45. Wilfert, J. N., Burke, J. P., Bloomer, H. A., and Smith, C. B.: Renal insufficiency associated with gentamicin therapy. J. Infect. Dis., 124: S148 (1971)

46. Presented in part at the 49th Annual Meeting of the Society for Pediatric Research. Atlanta. Georgia. May 3-4, 1979.

47. Requests for reprints should be addressed to: Dr. B. S. Arant, Department of Pediatrics, University of Texas Health Science Center at Dallas, 5323 Harry Hines Boulevard, Dallas, TX 75235 (USA).

48. This research was supported in part by NIH Grant HD-0906l and by a grant from the Southern Medical Association.

49. Received for publication January 14,1980

50. Accepted for publication May 12, 1980. 